\title{
Gas-Phase Selective Conjugate Addition of Methanol to Acetone for Methyl Vinyl Ketone Over $\mathrm{SnO}_{2}$ Nanoparticle Catalysts
}

\author{
Humberto V. Fajardo ${ }^{*, a}$, Luiz F. D. Probst ${ }^{a}$, Antoninho Valentini ${ }^{a}$, Neftalí L. V. Carreño ${ }^{b}$, \\ Adeilton P. Maciel ${ }^{c}$, Edson R. Leite ${ }^{c}$ and Elson Longo ${ }^{c}$ \\ ${ }^{a}$ Departamento de Química, Universidade Federal de Santa Catarina, CP 476, 88040-900 Florianópolis - SC, Brazil \\ ${ }^{b}$ Departamento de Química, Universidade Federal de Sergipe, 49100-000 São Cristóvão - SE, Brazil \\ ${ }^{c}$ Departamento de Química, Universidade Federal de São Carlos, CP 676, 13560-905 São Carlos - SP, Brazil
}

\begin{abstract}
Neste trabalho é apresentada a reação de condensação aldólica entre metanol e acetona promovida por nanopartículas de dióxido de estanho, não dopadas e dopadas com as terras raras Ce e Y. Diversas condições de relação molar metanol/acetona foram avaliadas, objetivando a obtenção com elevada seletividade do composto $\alpha, \beta$-insaturado, metil vinil cetona. As nanopartículas foram preparadas empregando-se o método dos precursores poliméricos. As amostras foram caracterizadas por meio de adsorção de $\mathrm{N}_{2}$ para determinação de área superficial específica (BET), difração de raios $\mathrm{X}$ (DRX), adsorção química de $\mathrm{CO}_{2}$, espectroscopia de fotoelétrons (XPS) e microscopia eletrônica de transmissão (MET). O comportamento catalítico observado para as amostras de $\mathrm{SnO}_{2}$ sugere que a relação molar metanol/acetona e a dopagem com as terras raras desempenham um papel importante na atividade catalítica do material e na seletividade aos produtos reacionais. Os resultados de DRX e XPS apontam para a formação de uma camada de segregação, para as amostras dopadas, devido ao tratamento térmico imposto. Essa camada de segregação afeta diretamente o comportamento catalítico do material frente à reação de condensação.
\end{abstract}

Aldol condensation between methanol and acetone, catalyzed by undoped and rare earths ( $\mathrm{Ce}$ and $\mathrm{Y}$ ) doped tin oxide nanoparticles is presented. Several methanol/acetone molar ratio conditions were evaluated aiming to produce methyl vinyl ketone as the main product. The undoped and doped ultrafine nanoparticles of tin oxide were prepared using the polymeric precursor method. The characterization was carried out by means of $\mathrm{N}_{2}$ adsorption (BET), X-ray diffraction (XRD), $\mathrm{CO}_{2}$ chemisorption, X-ray photoemission spectroscopy (XPS) and transmission electron microscopy (TEM). The catalytic behavior observed for $\mathrm{SnO}_{2}$ samples suggests that the methanol/acetone molar ratio and $\mathrm{Ce}$ and $\mathrm{Y}$ doping play an important role in the catalytic activity and in the product selectivity. The results from XRD and XPS pointed to the de-mixing process for the doped samples, due to the heat-treatment. This segregation layer contributes to the observed change in the catalytic behavior.

Keywords: heterogeneous catalysis, aldol condensation, methyl vinyl ketone, tin oxide

\section{Introduction}

Industrial condensation reactions are of great importance in the production of a number of key compounds, mainly because they lead to C-C bond formation. ${ }^{1,2}$ These reactions are typically catalyzed by bases, but can also proceed over acidic catalysts. ${ }^{2}$ Over 1.5 million tonnes of these chemicals are produced worldwide using homogeneous bases every year. It has been estimated that $30 \%$ of the selling price of these compounds is related

* e-mail: hfajardo@qmc.ufsc.br to product purification, recovery and waste treatment. For every 10 tonnes of product formed, the current homogeneous catalysts generate about 1 tonne of spent catalyst. ${ }^{1,3}$ For a better protection of the environment it is desirable to find solid bases that could substitute liquid catalysts and would also show all the advantages of heterogeneous catalysis. ${ }^{4}$ Therefore, solid base catalysis is an area of chemistry that offers an excellent opportunity for exploitation if suitable catalysts and processes can be identified and developed.

It is well known that methyl vinyl ketone (MVK) is effectively formed from the reaction of methanol with 
acetone over $\mathrm{MgO}$, which is a representative basic catalyst. ${ }^{5-8}$ It was recently shown that the modification of the nanometric-scale structure and the composition of particles leads to interesting selectivity changes in the methanol decomposition promoted by $\mathrm{SnO}_{2}$ nanoparticle catalysts. ${ }^{9}$ However, the influence of the nature of the active sites (the surface basicity of the oxide), on the performance of the catalysts was not investigated. Tin oxide has been used in a large range of technological applications, including sensors and catalysts. ${ }^{10}$ It is a well-established fact that semiconductor oxides, such as $\mathrm{SnO}_{2}$, have an excellent potential for these applications due to their high capacity to adsorb gaseous molecules and promote their reactions. ${ }^{11}$ Tin oxide is an amphoterous oxide, with a slight acid character. One of the most common ways to modify the characteristics of a material is by introducing dopants. Several studies have evaluated the effect of different dopants on the morphology and properties of tin oxide. ${ }^{9-14}$ Rare earth cations have, as yet, been little explored as tin oxide dopants for catalytic purposes. Nevertheless, the consensus is that their influence on the catalytic properties of $\mathrm{SnO}_{2}$ is associated with the acid/base characteristics of the oxides involved. ${ }^{11}$ The basic characteristics of rare earth oxides may favor some catalytic aspects such as adsorbing centers. In addition the study of basicity, in more sensitive reactions, is very important as a source of information about the different kinds of active sites.

Many works have been carried out to study the aldolization reaction in liquid phase, but few were carried out in gas phase heterogeneous catalysis. ${ }^{7,8}$ We have developed a catalytic method for C-C bond formation for the synthesis of methyl vinyl ketone from the condensation between methanol and acetone promoted by tin oxide nanoparticles undoped and doped with rare earths $\left(\mathrm{Y}_{2} \mathrm{O}_{3}\right.$ and $\left.\mathrm{CeO}_{2}\right)$.

The synthetic method based on the utilization of methanol instead of formaldehyde, producing in situ formaldehyde seems to be more interesting in the synthesis of vinylketones. Providing the starting formaldehyde by one of its commercial forms results in many technical difficulties.

Vinyl ketones are becoming increasingly important as polymeric photosensitizers and electro-conducting polymers. ${ }^{7}$ In view of the importance of both MVK and the utilization of methanol, the reaction of acetone with methanol was performed over a series of undoped and doped tin oxide nanoparticles and also under different methanol/acetone molar ratio conditions.

\section{Experimental}

Doped and undoped $\mathrm{SnO}_{2}$ samples were synthesized by the polymeric precursor method.9,10 This method is based on the chelation of cations (metals) by citric acid, in aqueous solution containing tin citrate, in the present case. Ethylene glycol is added later, in order to polymerize the organic precursor. The aqueous tin citrate solution was prepared from $\mathrm{SnCl}_{2} \cdot \mathrm{H}_{2} \mathrm{O}$ (Mallinckrodt Baker, USA, purity $>99.9 \%$ ) and citric acid (Merck, Germany, purity >99.9\%) with a citric acid/metal molar ratio of $3: 1$.

For the synthesis of the rare earth-doped $\mathrm{SnO}_{2}$ samples, an aqueous solution of a rare earth citrate was prepared from a rare earth nitrate (Y and Ce-nitrates, Alfa Aesar, USA, purity $>99.9 \%$ ) and citric acid with a citric acid/metal molar ratio of $3: 1$. The aqueous rare earth citrate solution was added in the proper amount to the aqueous tin citrate solution in order to obtain a doping level of $5 \mathrm{~mol} \%$ in all cases. Later, ethylene glycol was added to the citrate solutions, at a mass ratio of 40:60 in relation to citric acid, to promote the polymerization reaction. After several hours of polymerization at approximately $100{ }^{\circ} \mathrm{C}$, the polymeric precursors were heat-treated in two steps, initially at $300{ }^{\circ} \mathrm{C}$ for $6 \mathrm{~h}$ in air to promote the pre-pyrolysis, and then at several temperatures $\left(550-1100{ }^{\circ} \mathrm{C}\right)$ for $2 \mathrm{~h}$ also in air to allow the organic material to be completely oxidized and to promote the crystallization of the $\mathrm{SnO}_{2}$ phase.

The determination of the specific surface area of the samples was made by $\mathrm{N}_{2}$ adsorption/desorption isotherms (BET method) at liquid nitrogen temperature in an Autosorb-1C (Quantachrome Instruments). The $\mathrm{CO}_{2}$ adsorption isotherms at $300{ }^{\circ} \mathrm{C}$ were determined with the same instrument. The amount of irreversible $\mathrm{CO}_{2}$ uptake was obtained from the difference between the total adsorption of $\mathrm{CO}_{2}$ on the catalyst and a second adsorption series of $\mathrm{CO}_{2}$ determined after evacuation of the catalyst sample for $20 \mathrm{~min}$ at the same temperature.

X-ray diffraction (XRD; Siemens, D5000, equipped with graphite monochromator and $\mathrm{Cu} \mathrm{K} \alpha$ radiation) was used for the crystal phase determination. For the TEM/BFTEM/HRTEM, a drop of the powder suspension was deposited on a carbon-covered nickel grid. TEM analysis was performed using a $200 \mathrm{kV}$ Philips CM 200 microscope. The X-ray photoelectron spectra were taken using a commercial VG ESCA 3000 system. The base pressure of the analysis chamber was in the low $10^{-10}$ mbar range. The spectra were collected using $\mathrm{Mg} \mathrm{K} \alpha$ radiation and the overall energy resolution was about $0.8 \mathrm{eV}$. The concentration of the surface elements was calculated using the system's database after subtracting the background counts.

Gas phase catalytic vinylation of acetone to methyl vinyl ketone was carried out in a fixed-bed continuous flow reactor made of stainless steel, at atmospheric pressure, at $300{ }^{\circ} \mathrm{C}$, and loaded with $0.1 \mathrm{~g}$ of catalyst. Catalysts 
were first heated in a flow of helium up to $350{ }^{\circ} \mathrm{C}$ and maintained at that temperature for $1 \mathrm{~h}$. The reaction gas was composed of different methanol/acetone molar ratio $(1 / 2,1$ and 2$)$; the total flow rate of gas reaction was $60 \mathrm{~cm}^{3} \mathrm{~min}^{-1}$, with $\mathrm{He}$ as the carrier gas. Products were analyzed for $4 \mathrm{~h}$ of the continuous catalytic reaction by gas chromatography (SHIMADZU 14B GC instrument) with a flame ionization detector and a capillary nonpolar column (CBP1).

\section{Results and Discussion}

The characterization of undoped and rare earth doped tin oxide nanoparticles has been reported earlier. ${ }^{9,14}$ Figure 1 illustrates the XRD patterns of the phase evolution of the undoped and doped ( $\mathrm{Ce}$ and $\mathrm{Y}$ ) $\mathrm{SnO}_{2}$ particles annealed at different temperatures.

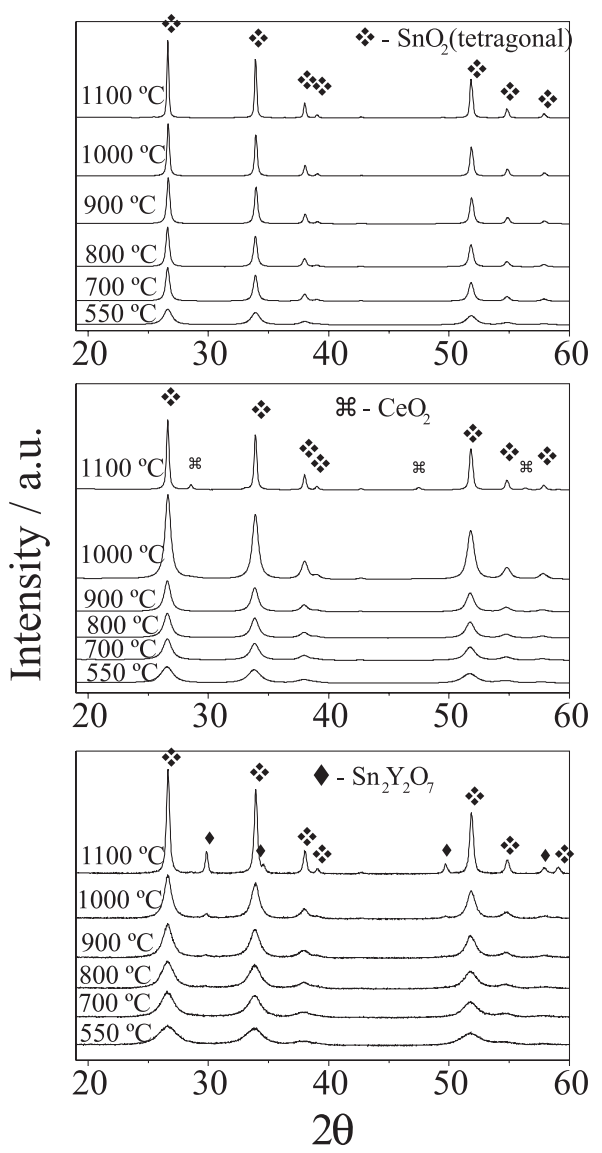

Figure 1. X-ray diffraction results showing the phase evolution of the undoped $\mathrm{SnO}_{2}, \mathrm{Ce}-\mathrm{SnO}_{2}, \mathrm{Y}-\mathrm{SnO}_{2}$ systems as a function of the heat-treatment temperature.

Diffraction peaks related to a secondary phase formation $\left(\mathrm{Sn}_{2} \mathrm{Y}_{2} \mathrm{O}_{7}\right)$ for $\mathrm{Y}$ doped $\mathrm{SnO}_{2}$ were observed above $900{ }^{\circ} \mathrm{C}$ of heat-treating temperatures. A secondary phase formation was observed for Ce doped $\mathrm{SnO}_{2}$ sample as well, however the $\mathrm{CeO}_{2}$ phase was detected at $1100{ }^{\circ} \mathrm{C}$ of annealing temperature. On the other hand, for the samples annealed at temperatures lower than this, only the tetragonal $\mathrm{SnO}_{2}$ phase was observed, suggesting the formation of a solid solution for the different dopants. The heat treatment promotes a segregation process, resulting in a surface with a different chemical composition. ${ }^{9}$ The X-ray diffraction patterns, associated with the Rietveld refinement method, were used to determine the crystallite size of the tin oxide samples (Table 1).

Table 1. Crystallite sizes measured by the Rietveld refinement and specific surface areas determined by $\mathrm{N}_{2}$ adsorption (BET), as a function of the annealing temperature

\begin{tabular}{lcccc}
\hline Samples & \multicolumn{2}{c}{$\begin{array}{c}\text { Crystallite size } \\
(\AA)\end{array}$} & \multicolumn{2}{c}{$\begin{array}{c}\text { Specific surface area } \\
\left(\mathrm{m}^{2} \mathrm{~g}^{-1}\right)\end{array}$} \\
& $550{ }^{\circ} \mathrm{C}$ & $1000{ }^{\circ} \mathrm{C}$ & $550{ }^{\circ} \mathrm{C}$ & $1000{ }^{\circ} \mathrm{C}$ \\
\hline $\mathrm{SnO}_{2}$ & 127.3 & 659.5 & 24 & 8 \\
$\mathrm{Ce}^{2} \mathrm{SnO}_{2}$ & 117.2 & 194.5 & 48 & 16 \\
$\mathrm{Y}_{-} \mathrm{SnO}_{2}$ & 52.2 & 143.4 & 63 & 17 \\
\hline
\end{tabular}

In order to better characterize the particle size variation due to the doping effect, bright field transmission electron microscopy (BF-TEM) measurements were carried out.

Figure 2 shows low magnification bright field (BFTEM) transmission electron microscopy images of Y- and Ce-doped $\mathrm{SnO}_{2}$ particles and undoped $\mathrm{SnO}_{2}$ particles, annealed at $550{ }^{\circ} \mathrm{C}$. These images reveal that these materials present nanometric particle sizes. The crystallite size measured by XRD-Rietveld is close to the particle size analyzed by TEM. These figures reveal that the doped materials present smaller particle sizes than the undoped material, as shown in Table 1. The decrease in the crystallite size due to the introduction of rare earths leads to an increase in the specific surface area (BET) (Table 1).
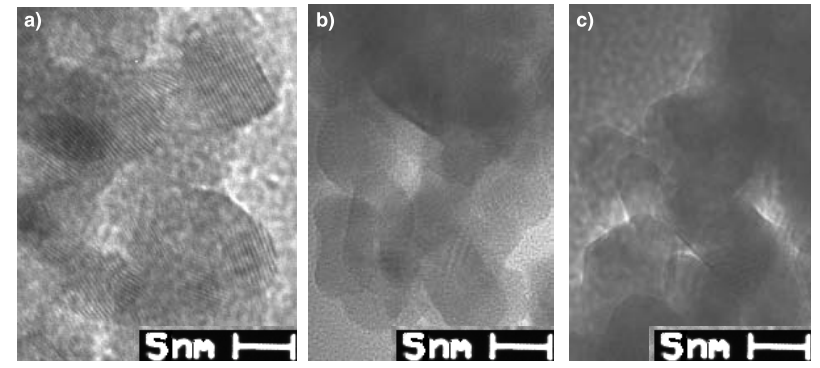

Figure 2. TEM images of the Y-doped (a), Ce-doped $\mathrm{SnO}_{2}$ (b) and pure $\mathrm{SnO}_{2}$ (c) powders, obtained by the polymeric precursor method and heat-treated at $550{ }^{\circ} \mathrm{C}$.

The results observed in the XRD analysis, secondary phase formations $\left(\mathrm{Sn}_{2} \mathrm{Y}_{2} \mathrm{O}_{7}\right.$ and $\left.\mathrm{CeO}_{2}\right)$ due to the annealing temperature, suggest that a de-mixing process occurs at higher temperatures $\left(\mathrm{T}>900{ }^{\circ} \mathrm{C}\right)$. In order to obtain more 
information about this de-mixing process, an X-ray photoemission spectroscopy (XPS) analysis was carried out. Figures $3 \mathrm{a}$ and $3 \mathrm{~b}$ show X-ray photoemission spectroscopy (XPS) results ( [rare earth] / [Sn] ratio) for the $\mathrm{Y}$ - and $\mathrm{Ce}$-doped $\mathrm{SnO}_{2}$ samples subjected to different thermal treatment temperatures.
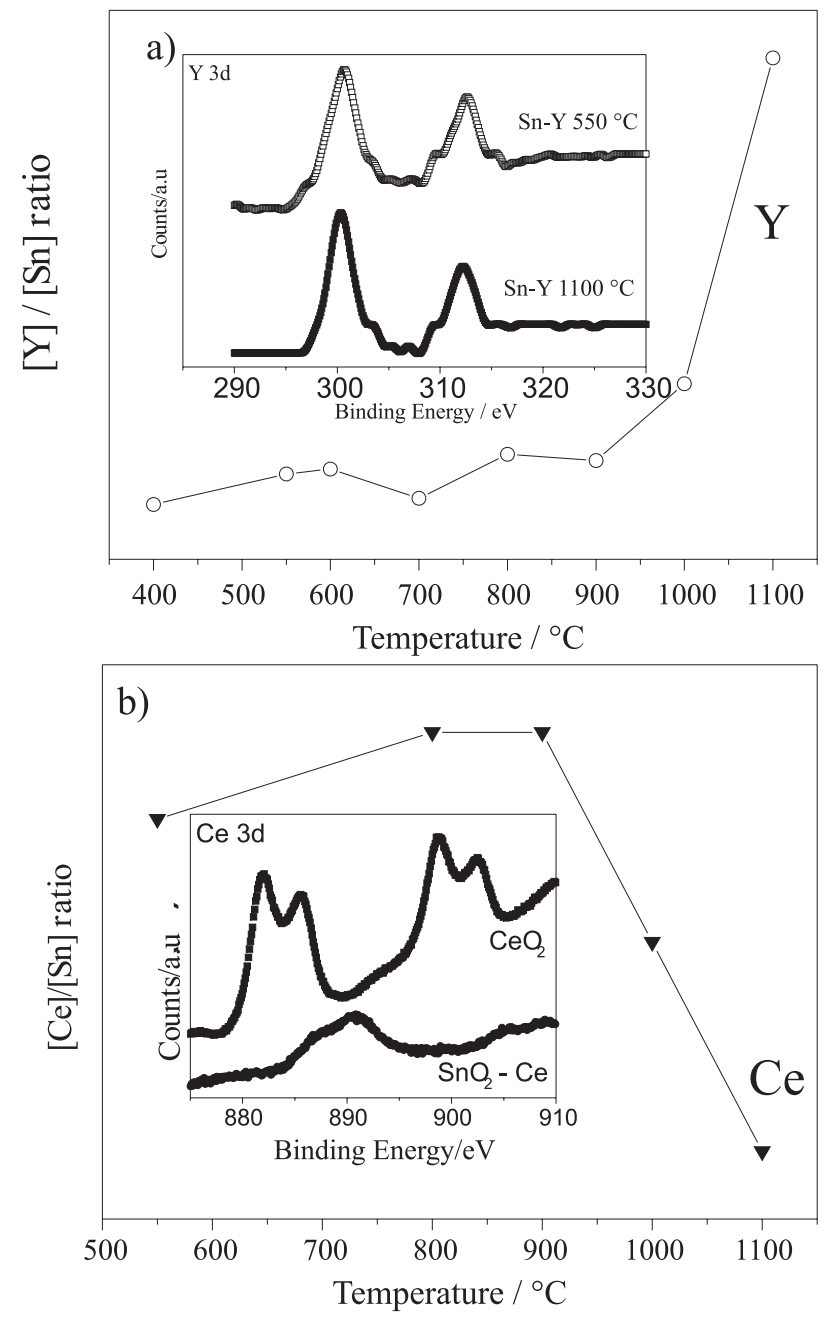

Figure 3. The XPS results of [rare earth]:[Sn] ratio for Y- and Cedoped $\mathrm{SnO}_{2}$ samples subjected to different treatment temperatures.

There is a general tendency for the concentration of $\mathrm{Y}$ on the surface of the samples to increase with the increase in annealing temperature. Both Y-doped samples shown in Figure $3 \mathrm{a}$ present the $3 \mathrm{~d} \mathrm{Y}$ profile, indicating the presence of a secondary phase $\left(\mathrm{Sn}_{2} \mathrm{Y}_{2} \mathrm{O}_{7}\right)$, which was detected in the XRD measurements. The results for the Cedoped $\mathrm{SnO}_{2}$ reveal a thermal behavior differing from that of the Y-doped samples. The $[\mathrm{Ce}] /[\mathrm{Sn}]$ concentration increases up to $900^{\circ} \mathrm{C}$, after which it drastically decreases as the annealing temperature rises. The inset shows the Ce 3d XPS lines (Figure 3b). This behavior agrees with the shape of the Ce XPS pattern suggesting a non-homogenous cover of $\mathrm{CeO}_{2}$ on the surface of the $\mathrm{Ce}-\mathrm{SnO}_{2}$ particles, differently from the homogenous covering of rare earth stanate observed in the Y-doped $\mathrm{SnO}_{2}$. It is clear, from the XPS results, that a surface rich in foreign cations is formed during the heat treatment. The de-mixing process observed for the Y-doped $\mathrm{SnO}_{2}$ is different from that of Ce-doped $\mathrm{SnO}_{2}$. These results are in agreement with the XRD data and show the formation of stanate during heat treatments. As mentioned earlier, the heat treatment promotes a segregation process, resulting in a surface with different chemical compositions. For the Y-doped $\mathrm{SnO}_{2}$ samples the ratio between [Y] and [Sn] increased with the heat treatment temperatures, indicating that the dopant migrated toward the surface. On the other hand, the ratio between $[\mathrm{Ce}]$ and [Sn] decreased above $900{ }^{\circ} \mathrm{C}$, suggesting that the dopant was expelled from the matrix.9,10

Carbon dioxide was the probe molecule used to determine the basic properties of the catalysts. The $\mathrm{CO}_{2}$ adsorption isotherms are very sensitive to the presence of polar groups or ions on the surface of the solid..$^{15}$ It was observed (Table 2) that with the increase in the heattreatment temperature of the samples the total $\mathrm{CO}_{2}$ adsorption is favored. This behavior indicates a change in the surface properties of the samples due to the annealing temperature, which can promote different results in the catalytic reaction. It is important to point out the irreversible $\mathrm{CO}_{2}$ adsorption for the undoped and Y-doped $\mathrm{SnO}_{2}$ samples. These results suggest that a higher annealing temperature promotes an increase in the amount of stronger basic sites. On the other hand, for the Ce-doped $\mathrm{SnO}_{2}$ samples treated at $1000{ }^{\circ} \mathrm{C}$, the isotherms did not display irreversible $\mathrm{CO}_{2}$ adsorption. It is evident that the $\mathrm{CO}_{2}$ adsorption capacity of $\mathrm{SnO}_{2}$ samples can be significantly affected by the doping chemical species and by the annealing treatment (Table 2).

Table 2. The total and irreversible amounts of $\mathrm{CO}_{2}$ adsorbed, uptake at $300{ }^{\circ} \mathrm{C}$, on undoped and doped samples of tin oxide

\begin{tabular}{lcccc}
\hline Samples & $\begin{array}{c}\text { Total } \mathrm{CO}_{2} \\
\left.(\mu \mathrm{mol} \mathrm{m})^{-2}\right)\end{array}$ & \multicolumn{2}{c}{$\begin{array}{c}\text { Irreversible } \mathrm{CO}_{2} \\
\left.(\mu \mathrm{mol} \mathrm{m})^{-2}\right)\end{array}$} \\
\hline & $550^{\mathrm{a}}$ & $1000^{\mathrm{a}}$ & $550^{\mathrm{a}}$ & $1000^{\mathrm{a}}$ \\
$\mathrm{SnO}_{2}$ & $300^{\mathrm{b}}$ & $300^{\mathrm{b}}$ & $300^{\mathrm{b}}$ & $300^{\mathrm{b}}$ \\
$\mathrm{Ce}-S n O_{2}$ & 0.34 & 0.93 & - & 0.16 \\
$\mathrm{Y}-S n O_{2}$ & 0.61 & 1.48 & 0.12 & - \\
\hline
\end{tabular}

a annealing temperature $\left({ }^{\circ} \mathrm{C}\right) ;{ }^{b}$ isotherm temperature adsorption $\left({ }^{\circ} \mathrm{C}\right)$.

The catalytic activity of the nanoparticles was followed by the acetone conversion. The acetone conversion presented in Table 3 indicates the effective contribution of the doping to the catalytic activity. These 
observations are in agreement with the higher surface area observed for the doped samples, and with the $\mathrm{CO}_{2}$ adsorption increase.

The increase in the annealing temperature from $550{ }^{\circ} \mathrm{C}$ to $1000^{\circ} \mathrm{C}$ resulted in a lower surface area and lower acetone conversion. However, if we consider the specific activity, the $\mathrm{Ce}$ and $\mathrm{Y}$ doped samples present a higher value with the annealing temperature increase.

This behavior points to the influence of the surface property changes on the catalytic activity, promoted by the Ce and Y doping. Such results may be related with those observed by the XRD and XPS analyses, where the samples heat-treated at $1000{ }^{\circ} \mathrm{C}$ showed a higher doping concentration on their surfaces. ${ }^{9}$

The products selectivity presented in Table 3 shows MVK as the main compound obtained. The MVK selectivity $(\sim 64 \%)$ was practically the same for the undoped and the doped $\mathrm{SnO}_{2}$ samples, annealed at $550{ }^{\circ} \mathrm{C}$. The $\mathrm{Ce}-\mathrm{SnO}$, sample annealed at $1000^{\circ} \mathrm{C}$ displayed low selectivity for MVK. This may be associated with the high amount of secondary phase $\left(\mathrm{CeO}_{2}\right)$ that is formed on the surface of the sample, as the annealing temperature increases, and to the fact that the sample did not present irreversible $\mathrm{CO}_{2}$ adsorption (related to strong basic sites). The ability to abstract a proton from a molecule adsorbed on the catalyst surface depends on two factors: the strength of the basic surface site and the acidity of the reactant proton. For ketones, the $\alpha$-protons are capable of reacting with strong bases to yield the conjugate base, a resonance stabilized enolate ion. ${ }^{16,17}$ The aldolization reaction of acetone and methanol promoted by $\mathrm{SnO}_{2}$ samples leads to the $\mathrm{C}-\mathrm{C}$ bond formation. This process may proceed via a formaldehyde intermediate formed from methanol by dehydrogenation, followed by the condensation of formaldehyde with the anionic intermediate. This intermediate is formed by the dehydrogenation (or deprotonation) of the substrate (acetone) on the basic sites. Thus, a subsequent reaction occurs, which is effective to some extent for the vinylation of acetone to methyl vinyl ketone. On the other hand, methyl ethyl ketone (MEK) is also formed by the reaction of acetone with methanol and isopropyl alcohol (IPA) is formed by the hydrogenation of acetone. However, undesirable secondary products can be formed during the catalytic conversion of acetone, ${ }^{5-8}$ as illustrated in Scheme 1. They come from the selfcondensation of acetone mainly diacetone alcohol, selfcondensation of methanol (dimethyl ether), polymerization of MVK, as well as methylformate that should be formed by the reaction of formaldehyde with methanol (and the cracking process).

Table 3. Conversion and selectivity values for undoped and doped $\mathrm{SnO}_{2}$ samples at 2:1 methanol : acetone molar ratio condition

\begin{tabular}{|c|c|c|c|c|c|c|}
\hline \multirow[t]{2}{*}{ Samples } & \multirow[t]{2}{*}{ Conversion (\%) } & \multicolumn{4}{|c|}{ Selectivity (\%) } & \multirow[t]{2}{*}{ Methanol:Acetone } \\
\hline & & MVK & MEK & IPA & $\mathrm{CCP}$ & \\
\hline $\mathrm{SnO}_{2}\left(550^{\circ} \mathrm{C}\right)$ & 2.5 & 62.0 & 1.0 & 11.3 & 25.6 & $2: 1$ \\
\hline $\mathrm{SnO}_{2}\left(1000^{\circ} \mathrm{C}\right)$ & 0.5 & 56.1 & 0.0 & 18.0 & 25.8 & $2: 1$ \\
\hline $\mathrm{Y}^{-\mathrm{SnO}_{2}}\left(550^{\circ} \mathrm{C}\right)$ & 9.9 & 63.2 & 12.8 & 5.0 & 18.9 & $2: 1$ \\
\hline $\mathrm{Y}^{-\mathrm{SnO}_{2}}\left(1000^{\circ} \mathrm{C}\right)$ & 4.5 & 65.1 & 5.8 & 23.1 & 5.9 & $2: 1$ \\
\hline $\mathrm{Ce}-\mathrm{SnO}_{2}\left(550^{\circ} \mathrm{C}\right)$ & 6.2 & 65.4 & 9.6 & 8.5 & 16.4 & $2: 1$ \\
\hline $\mathrm{Ce}-\mathrm{SnO}_{2}\left(1000^{\circ} \mathrm{C}\right)$ & 5.5 & 55.3 & 7.2 & 15.6 & 21.7 & $2: 1$ \\
\hline
\end{tabular}

(MVK) methyl vinyl ketone; (MEK) methyl ethyl ketone; (IPA) isopropyl alcohol; (CCP) cracking and condensations products.

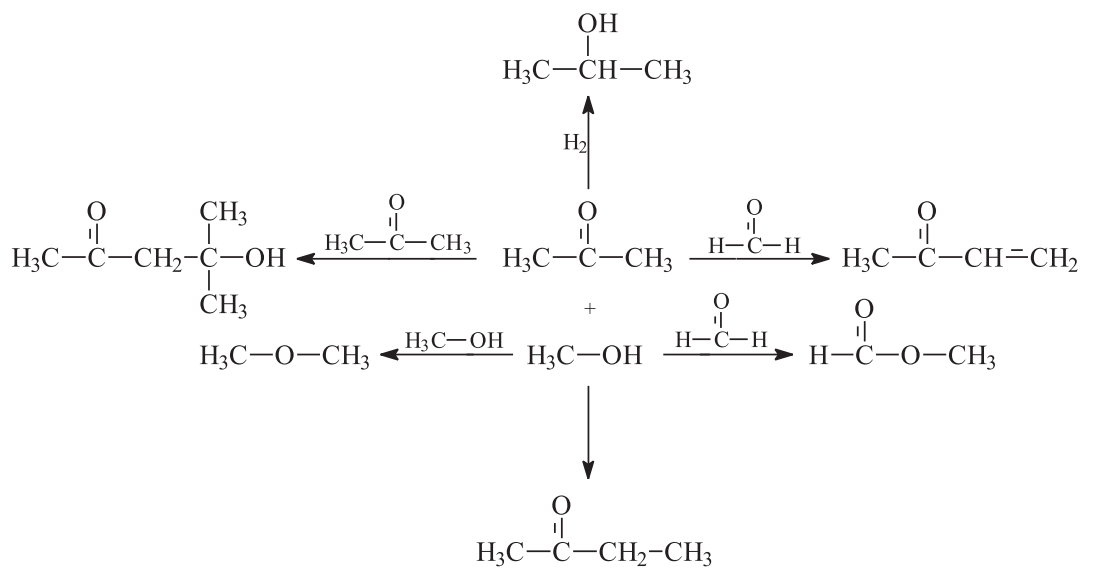

Scheme 1. Scheme of formation of main reaction products in the aldol condensation between methanol and acetone. 
The catalyst selectivity can be influenced by the acidic-basic properties on the oxide surface during the cross-coupling of acetone and methanol, and by the dehydrogenation-dehydration processes preferentially on the basic surface. ${ }^{5}$ The $\mathrm{Y}-\mathrm{SnO}_{2}$, sample showed an increase in MVK selectivity with the increase in the annealing temperature accompanied by the decrease in the secondary products. These results emphasize the $\mathrm{Sn}_{2} \mathrm{Y}_{2} \mathrm{O}_{7}$ contribution to the specific catalytic activity for the sample, in spite of the decrease in the conversion value.

In order to acquire more information about the catalytic process, the reaction was carried out under two other methanol/ acetone molar ratio conditions ( 1 and 1/2). These catalytic tests were performed with the $\mathrm{Y}-\mathrm{SnO}_{2}$ sample annealed at $550{ }^{\circ} \mathrm{C}$ due to the higher acetone conversion, and with the $\mathrm{Ce}-\mathrm{SnO}_{2}$, sample annealed at $1000^{\circ} \mathrm{C}$ due to the decrease in the [Ce] in the catalyst surface (XPS result, Figure 3).

Figure 4 shows the acetone conversion obtained with distinct methanol/acetone molar ratios for the catalysts. A lower ratio of acetone conversion is observed with an increase in acetone concentration. Such behavior may be related to the catalyst/acetone mass ratio decrease with the acetone increase. This result is in accordance with the first stage of the aldol condensation mechanism, where basic sites catalyze the carbanion formation by the abstraction of the $\alpha$-proton of acetone. The number of basic sites for the proton abstraction is constant while acetone concentration increases, and consequently there is a reactant conversion $(\%)$ decrease..$^{18}$

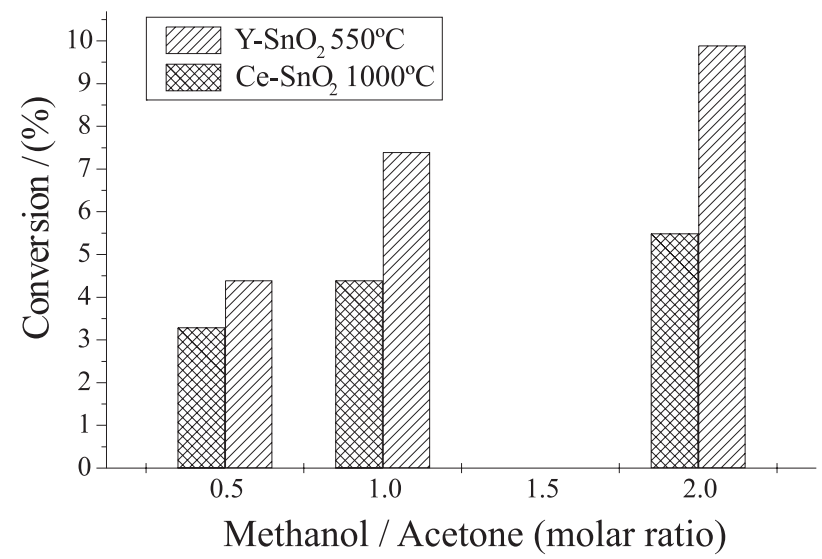

Figure 4. Acetone conversion obtained with distinct methanol/acetone molar ratios.

The best results were obtained with the reactant ratio (methanol/acetone) of 2. Not only a higher acetone conversion is observed, but, as one can see in Figure 5, lower methanol concentrations contribute to a lower MVK selectivity. These results show the role of methanol in the process. With a lower methanol presence there is a lower formaldehyde (in situ) production, which will result in lower MVK and MEK selectivities. In addition IPA seems to be formed by hydrogen transfer from methanol to acetone. ${ }^{5}$

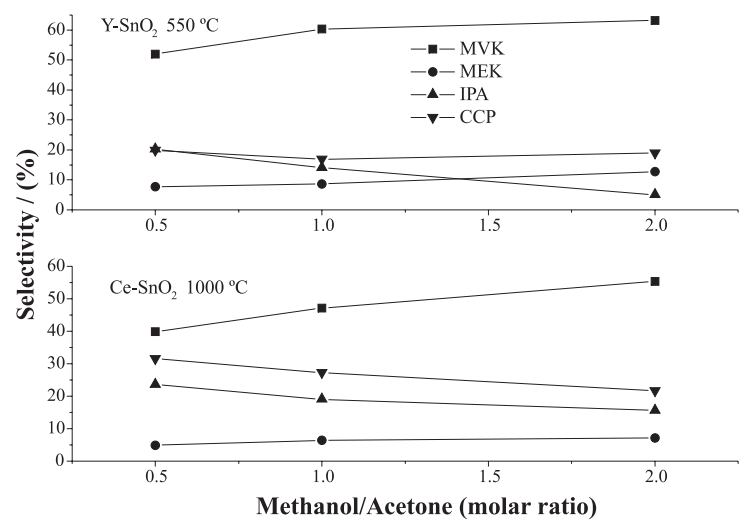

Figure 5. Selectivity for the main reaction products as a function of the methanol/acetone molar ratio for the $\mathrm{Y}^{-\mathrm{SnO}_{2}}\left(550{ }^{\circ} \mathrm{C}\right)$ and $\mathrm{Ce}-\mathrm{SnO}_{2}\left(1000^{\circ} \mathrm{C}\right)$ samples.

The material properties, such as surface area, crystallite size, basicity/base strength distribution, and the catalytic activity/selectivity of the catalysts in the aldolization process are strongly influenced by rare earth doping, by annealing temperatures and also by methanol/acetone molar ratio conditions. The surface property changes, due to the annealing temperature increase, promoted a variation in the product selectivities.

\section{Conclusions}

The $\mathrm{SnO}_{2}$-based nanoparticles were shown to be active and selective catalysts for the condensation between methanol and acetone in order to obtain MVK. Doping with rare earths provided an improvement in the activity of the materials, maintaining the high selectivity levels obtained by the pure sample. These results were obtained by the changes in the surface of the material due to the addition of dopants and the thermal treatment employed. The modifications in the basic sites of undoped and doped tin oxide particles, revealed by $\mathrm{CO}_{2}$ adsorption and by the catalytic measurements, suggest that the addition of cerium and yttrium leads to an increase in the basicity strength of the catalysts. On analysing all the results, the methanol/acetone molar ratio of 2 was selected due to its highest conversion and selectivity to MVK values.

\section{References}

1. Kelly, G. J.; King, F.; Kett, M.; Green Chem. 2002, 4, 392.

2. Lippert, S.; Baumann, W.; Thomke, K.; J. Mol. Catal. A: Chem. 1991, 69, 199. 
3. Tanabe, K.; Hoelderich, W. F.; Appl. Catal. A. 1999, 181, 399.

4. Rao, K. K.; Gravelle, M.; Valente, J. S.; Figueras, F.; J. Catal. 1998, 173, 115 .

5. Ueda, W.; Yokoyama, T.; Morooka, Y.; Ikawa, T.; J. Chem. Soc., Chem. Commun. 1984, 1, 39.

6. Huang, M.; Zielinski, P. A.; Moulod, J.; Kaliaguine, S.; Appl. Catal. A. 1994, 118, 33.

7. Kurokawa, H.; Ueda, W.; Morooka, Y.; Ikawa, T.; Abstracts of the $1^{o}$ International Symposium Catalyse Heterogène et Chime Fine, Poitiers, France, 1988, 1, 110.

8. Hassouni, R.; Cressely, J.; Idriss, H.; Kiennemann, A.; Abstracts of the $1^{\circ}$ International Symposium Catalyse Heterogène et Chime Fine, Poitiers, France, 1988, 1, 118.

9. Carreño, N. L. V.; Maciel, A. P.; Leite, E. R.; Lisboa-Filho, P. N.; Longo, E.; Valentini, A.; Probst, L. F. D.; Paiva-Santos, C. O.; Schreiner, W. H.; Sens. Actuators B Chem. 2002, 86, 185.

10. Weber, I. T.; Maciel, A. P.; Lisboa-Filho, P. N.; Longo, E.; Leite, E. R.; Paiva-Santos, C. O.; Maniette, Y.; Schreiner, W. H.; Nano Lett. 2002, 2, 969.

11. Weber, I. T.; Valentini, A.; Probst, L. F. D.; Longo, E.; Leite, E. R.; Sens. Actuators B Chem. 2004, 97, 31.
12. Leite, E. R.; Weber, I. T.; Longo, E.; Varela, J. A.; Adv. Mater. 2000, 12, 965 .

13. Lu, F.; Liu, Y.; Dong, M.; Wang, X.; Sens. Actuators B Chem. 2000, 66, 225.

14. Leite, E. R.; Maciel, A. P.; Weber, I. T.; Lisboa-Filho, P. N.; Longo, E.; Paiva-Santos, C. O.; Andrade, A. V. C.; Pakoscimas, C. A.; Maniette, Y.; Schreiner, W. H.; Adv. Mater. 2002, 14, 905 .

15. Roelofs, J. C. A. A.; van Dillen, A. J.; de Jong, K. P.; Catal. Today 2000, 60, 297.

16. Baumann, W.; J. Mol. Catal. A: Chem. 1991, 69, 117.

17. March, J.; Advanced Organic Chemistry - Reaction, Mechanisms and Structures, $4^{\text {th }}$ ed., Wiley: New York, 1992.

18. Pérez, C. N.; Henriques, C. A.; Zonno, I. V.; Monteiro, J. L. F.; Abstracts of the $11^{\circ}$ Congresso Brasileiro de Catálise and $1^{\circ}$ Congresso de Catálise no Mercosul, Bento Gonçalves, Brazil, 2001, 706.

Received: April 24, 2004 Published on the web: March 15, 2005

FAPESP helped in meeting the publication costs of this article. 